BMC

Plant Biology

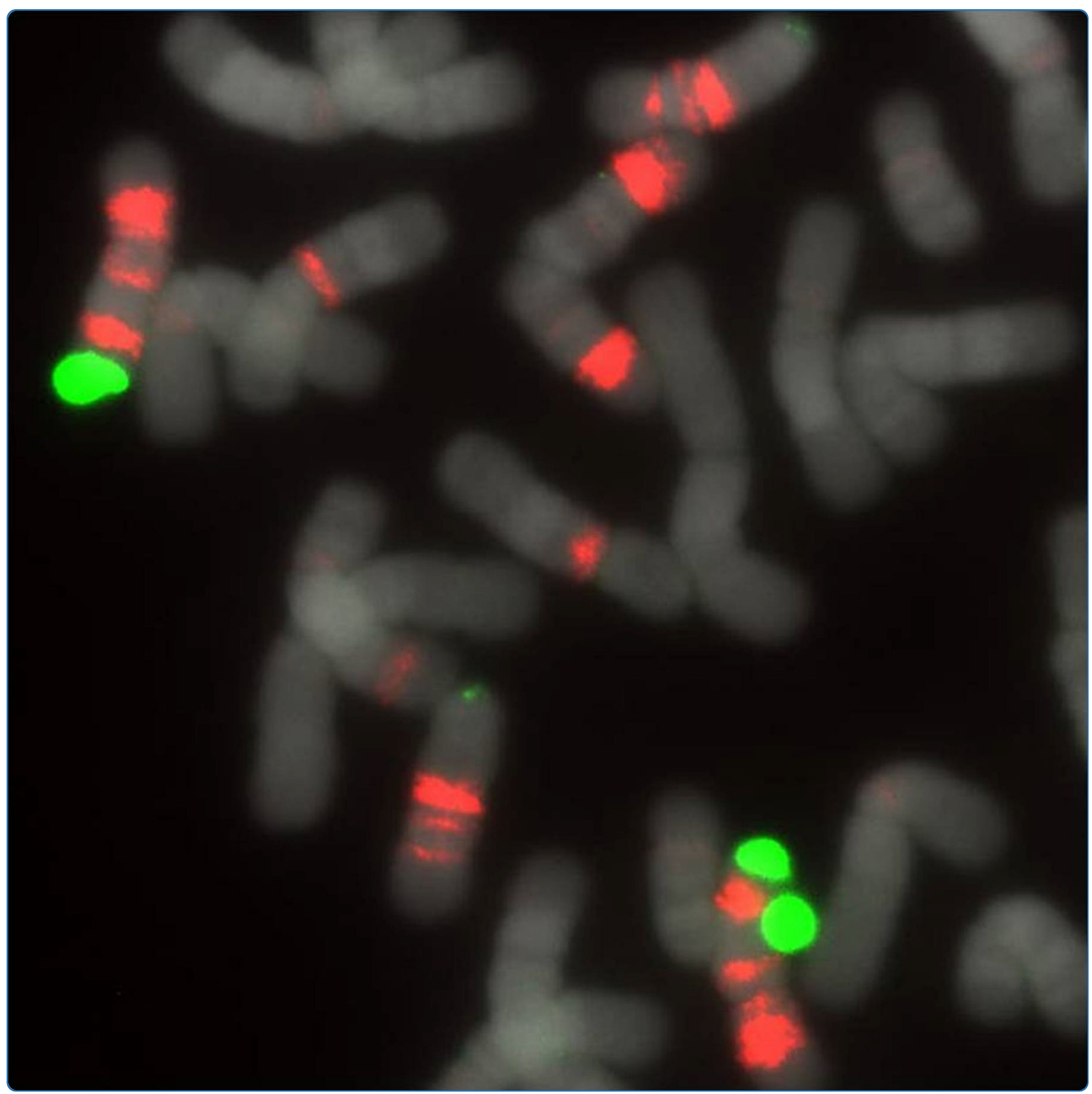

Dynamic distribution patterns of ribosomal DNA and chromosomal evolution in Paphiopedilum, a lady's slipper orchid

Lan and Albert

C Biomed Central

Lan and Albert BMC Plant Biology 2011, 11:126 http://www.biomedcentral.com/1471-2229/11/126 (12 September 2011) 


\title{
Dynamic distribution patterns of ribosomal DNA and chromosomal evolution in Paphiopedilum, a lady's slipper orchid
}

\author{
Tianying Lan and Victor A Albert
}

\begin{abstract}
Background: Paphiopedilum is a horticulturally and ecologically important genus of ca. 80 species of lady's slipper orchids native to Southeast Asia. These plants have long been of interest regarding their chromosomal evolution, which involves a progressive aneuploid series based on either fission or fusion of centromeres. Chromosome number is positively correlated with genome size, so rearrangement processes must include either insertion or deletion of DNA segments. We have conducted Fluorescence In Situ Hybridization (FISH) studies using 5 S and $25 \mathrm{~S}$ ribosomal DNA (rDNA) probes to survey for rearrangements, duplications, and phylogenetically-correlated variation within Paphiopedilum. We further studied sequence variation of the non-transcribed spacers of $5 \mathrm{~S}$ rDNA (5S-NTS) to examine their complex duplication history, including the possibility that concerted evolutionary forces may homogenize diversity.

Results: $5 \mathrm{~S}$ and $25 \mathrm{~S}$ rDNA loci among Paphiopedilum species, representing all key phylogenetic lineages, exhibit a considerable diversity that correlates well with recognized evolutionary groups. $25 \mathrm{~S}$ rDNA signals range from 2 (representing 1 locus) to 9, the latter representing hemizygosity. 5S loci display extensive structural variation, and show from 2 specific signals to many, both major and minor and highly dispersed. The dispersed signals mainly occur at centromeric and subtelomeric positions, which are hotspots for chromosomal breakpoints. Phylogenetic analysis of cloned 5S rDNA non-transcribed spacer (5S-NTS) sequences showed evidence for both ancient and recent post-speciation duplication events, as well as interlocus and intralocus diversity.

Conclusions: Paphiopedilum species display many chromosomal rearrangements - for example, duplications, translocations, and inversions - but only weak concerted evolutionary forces among highly duplicated 5S arrays, which suggests that double-strand break repair processes are dynamic and ongoing. These results make the genus a model system for the study of complex chromosomal evolution in plants.
\end{abstract}

\section{Background}

Paphiopedilum, a genus of approximately 80 species indigenous to tropical and subtropical Southeast Asia, is among the most widely grown and hybridized of all orchids. Species of Paphiopedilum are also ecologically important narrow endemics in various mainland and island habitats, which range from montane rainforest to seaside cliffs [1]. Karyological studies of Paphiopedilum have revealed considerable chromosomal variation, which ranges from $2 \mathrm{n}=26$ to $2 \mathrm{n}=42$, in aneuploid increments suggestive of centric fission [2]. Basic molecular phylogenetic

\footnotetext{
* Correspondence: vaalbert@buffalo.edu
Department of Biological Sciences, University at Buffalo, Buffalo, NY 14260,

* Correspondence: vaalbert@buffalo.edu
Department of Biological Sciences, University at Buffalo, Buffalo, NY 14260,
} USA

(c) 2011 Lan and Albert; licensee BioMed Central Ltd. This is an Open Access article distributed under the terms of the Creative Commons Attribution License (http://creativecommons.org/licenses/by/2.0), which permits unrestricted use, distribution, and reproduction in any medium, provided the original work is properly cited.

information on the genus is available [3]. Subgenus Parvisepalum, which is sister to the rest of the genus, has $2 n=26$ metacentric chromosomes, whereas the type subgenus Paphiopedilum includes both clades of $2 n=26$ species and two distinct lineages of species that bear greater than 26 chromosomes, with the number of telocentrics equal to twice the number of metacentrics that ostensibly split [3]. Haploid genome size is extremely large in these orchids, ranging from 16.1 to 35.1 megabases $(\mathrm{Mb})$ [4]. Chromosome number has been shown to be positively correlated with genome size [4], so rearrangement processes must include either insertion or deletion of DNA segments.

General issues in plant chromosomal evolution include the contribution of rearrangements to genome 
structure and size. Rearrangement processes involve double-strand break repair, which occurs frequently at hotspots in pericentromeric and telomeric regions $[5,6]$. Gene duplications may be caused by unequal crossing over, retrotransposition, or genome duplication [7]. Tandem repeats duplication or segmental duplication is one of the possible outcomes of unequal crossing over $[7,8]$. These phenomena may be investigated empirically through use of Fluorescence In Situ Hybridization (FISH) on highly repetitive DNA loci subject to concerted evolution, such as the $18 \mathrm{~S}-5.8 \mathrm{~S}-25 \mathrm{~S}$ (45S) and $5 \mathrm{~S}$ ribosomal DNA (rDNA) arrays, which may show duplication or evidence for rearrangement-producing heterologous recombination [9]. Infrageneric comparative rDNA FISH analyses, in which mobility and patterning have been systematically investigated as species-specific karyotype markers, are common in the literature [10-14]. We use such analyses here to document chromosomal dynamics in Paphiopedilum. FISH has been applied previously to Paphiopedilum, but in a limited manner only, and especially in hybrids $[15,16]$.

Both $45 \mathrm{~S}$ and $5 \mathrm{~S}$ rDNAs in plants are characterized by intergenic spacers. 5S rDNA non-transcribed spacer (5SNTS) sequences have seen some use as phylogenetic markers [17-21]. However, most studies of 5S-NTS to-date have employed direct sequencing of PCR products, and there is evidence that the NTS both within and among arrays can show polymorphism. We have cloned 5S-NTS segments in Paphiopedilum in order to study past and ongoing gene duplication events and the possibility of gene conversion both within arrays and among duplicated loci.

We briefly report distribution patterns of rDNA signals from a phylogenetic systematic perspective [22] according to accepted section-level classification. We do not aim to provide complete karyotypic comparisons, nor a full cytotaxonomic treatment; rather, we concern ourselves with demonstrable evidence for dynamic rearrangements during the evolution of Paphiopedilum. 5S-NTS sequence data are also compared with a phylogenetic hypothesis in order to ascertain duplication history of paralogs.

\section{Results}

Distribution patterns of ribosomal DNA by Fluorescence In Situ Hybridization, according to phylogeny and section-level classification

\section{Section Parvisepalum}

Section Parvisepalum is the sister group of all other Paphiopedilum species (Figure 1). Two to four $25 \mathrm{~S}$ rDNA signals are apparent (Figure 2) among $2 n=26$ chromosomes, with two signals most parsimoniously interpretable as the basal condition since this state is shared by the outgroup genera Mexipedium and Phragmipedium (unpublished data; [23]). With 2 signals being

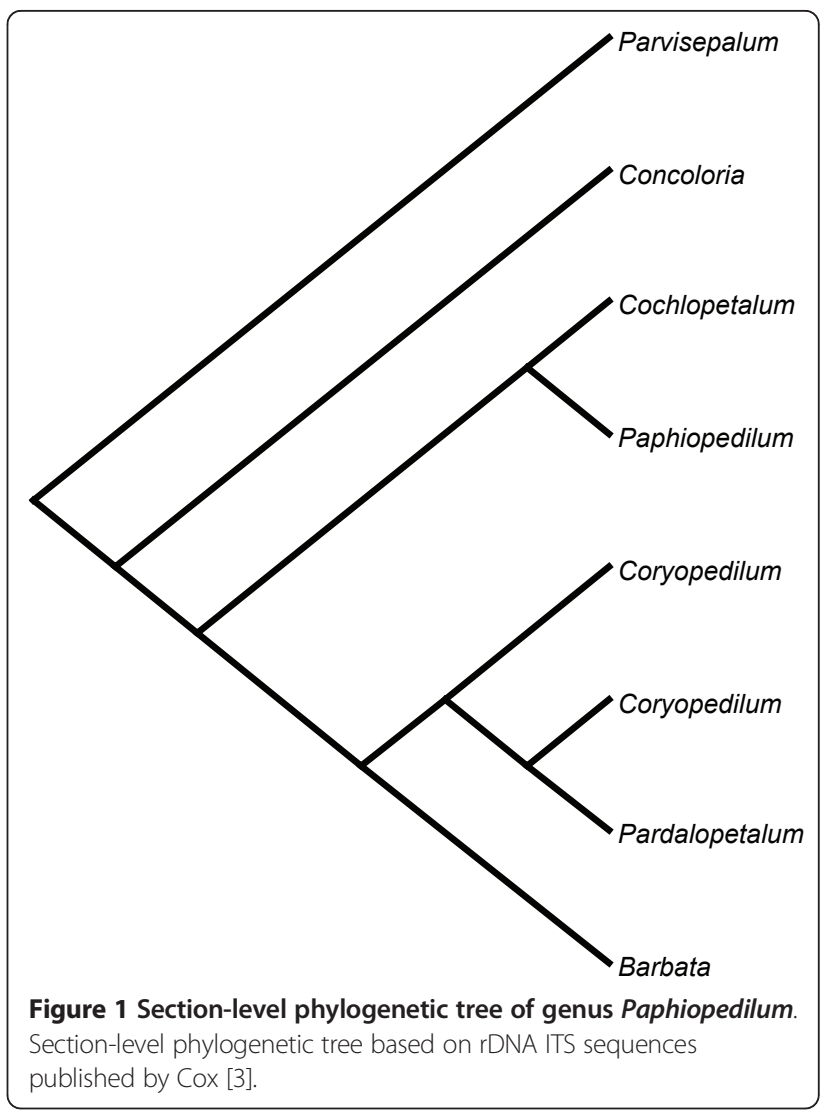

the inferred primitive condition, rearrangement by duplication is observed in Paphiopedilum armeniacum, $P$. emersonii and $P$. hangianum, which have more loci. 5S rDNA patterns are stable, showing 2 subtelomeric signals that are usually closely linked with one pair of $25 \mathrm{~S}$ signals (Table 1). In P. delenatii, translocation of either the $5 \mathrm{~S}$ or 25S rDNA locus has occurred. This phenomenon is also seen in P. malipoense, with its two chromosomes that show hemizygous $25 \mathrm{~S}$ and $5 \mathrm{~S}$ rDNA signals, respectively.

\section{Section Concoloria}

Species of section Concoloria show two 25S and 5S signals (Table 1$)$, each on separate chromosomes ( $2 n=26$ total), similarly to Paphiopedilum delenatii of section Parvisepalum, except in that the $5 \mathrm{~S}$ signals are interstitially instead of subtelomerically placed (Figure 3 ).

\section{Section Cochlopetalum}

Section Cochlopetalum displays an aneuploid number of chromosomes, the telocentrics of which have been suggested to descend via centric fission from 25 diploid metacentrics [2]. According to phylogenetic relationships known at present (Figure 1), and the centric fission hypothesis, sections Cochlopetalum and Barbata (with telocentrics descended from 26 diploid metacentrics) have evolved aneuploid increase independently. All four species studied here have two telomeric 25S rDNA signals, and 4 major $5 \mathrm{~S}$ rDNA signals (Figure 4; Table 1). 

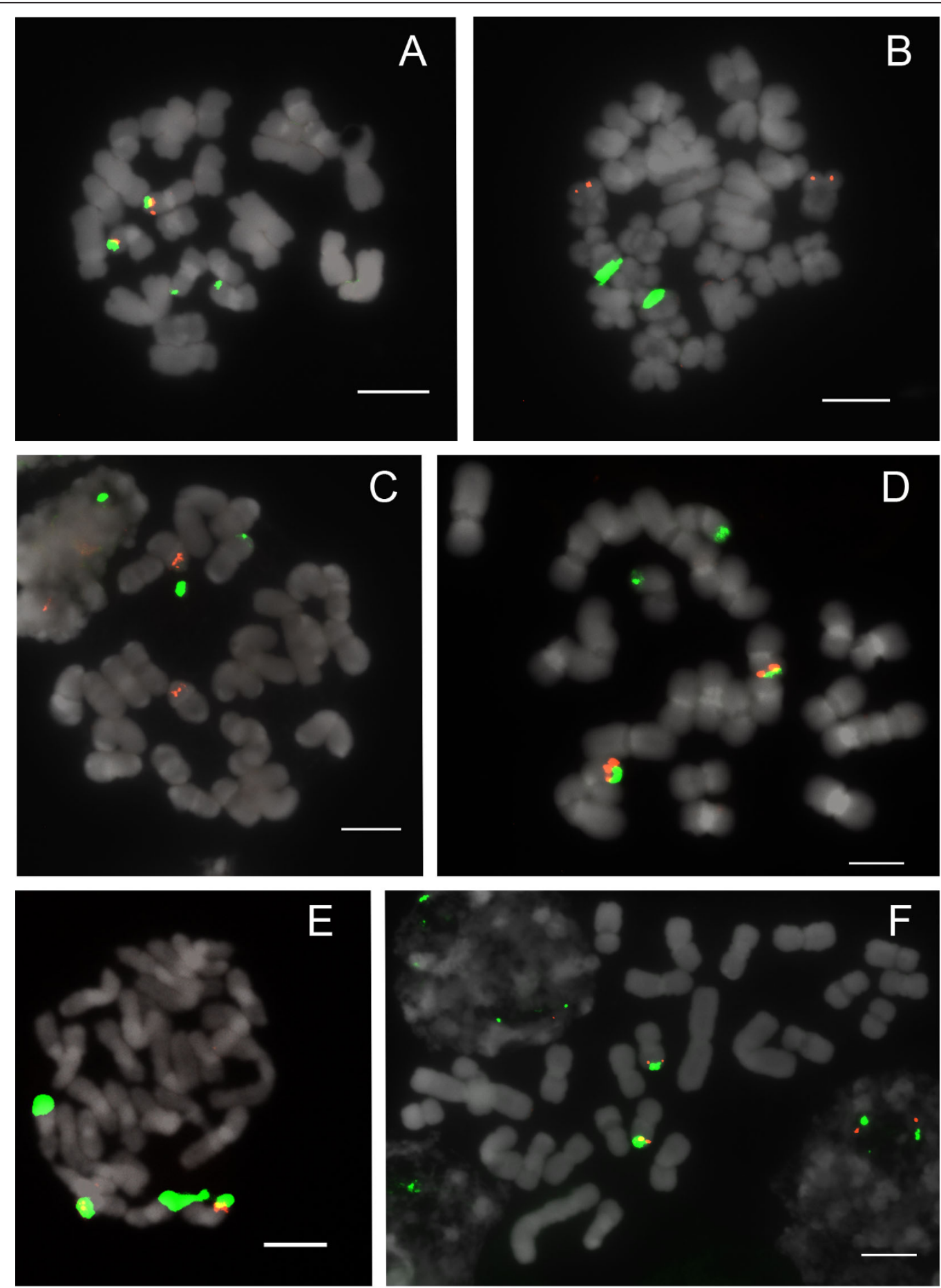

Figure 2 FISH of $25 \mathrm{~S}$ and 5 S rDNA to metaphase chromosomes of Paphiopedilum section Parvisepalum. (A) Paphiopedilum emersonii, (B) P. delenatii, (C) P. malipoense, (D) P. hangianum, (E) P. armeniacum, (F) P. micranthum. 25S rDNA (green) and 5S rDNA (red) probes were simultaneously detected in all Paphiopedilum species. Chromosomes were counterstained with DAPI. All scale bars $=10 \mu \mathrm{m}$.

All 4 species have multiple dispersed $5 \mathrm{~S}$ signals, rather unlike species of sections Parviflora and Concoloria, and these, like the major loci, are mostly subtelomeric, pericentromeric and centromeric in position. The 2 species with $2 \mathrm{n}=32$ chromosomes, Paphiopedilum liemianum (Figure 4C) and P. primulinum (Figure 4A), both have two $5 \mathrm{~S}$ bands localized on the same chromosomes as the $25 \mathrm{~S}$ signals, whereas only a single $5 \mathrm{~S}$ band is seen on the 
Table 1 Paphiopedilum species studied, diploid chromosome numbers, rDNA FISH patterns, and 5S-NTS sequence polymorphic sites

\begin{tabular}{|c|c|c|c|c|c|c|c|c|}
\hline \multirow[b]{3}{*}{ Taxon } & \multirow[b]{3}{*}{$2 n$} & \multicolumn{4}{|c|}{ Number of rDNA sites } & \multicolumn{2}{|c|}{ Positions of rDNA sites ${ }^{b}$} & \multirow[b]{3}{*}{ 5S-NTS Polymorphic sites } \\
\hline & & \multirow[b]{2}{*}{$25 S$} & \multicolumn{2}{|r|}{$5 S$} & \multirow{2}{*}{$\begin{array}{c}25 \mathrm{~S}+5 \mathrm{~S} \\
\text { Co-localization }\end{array}$} & \multirow[b]{2}{*}{$5 S$} & \multirow[b]{2}{*}{$25 S$} & \\
\hline & & & major & visible sites ${ }^{a}$ & & & & \\
\hline \multicolumn{9}{|l|}{ Paphiopedilum } \\
\hline \multicolumn{9}{|l|}{ Subg. Parvisepalum } \\
\hline \multicolumn{9}{|l|}{ Sect. Parvisepalum } \\
\hline armeniacum & 26 & 4 & 2 & 2 & 2 & st & $t$ & 104 \\
\hline delenatii & 26 & 2 & 2 & 2 & 0 & st & $\mathrm{t}$ & 178 \\
\hline emersonii & 26 & 4 & 2 & 2 & 2 & st & t & 124 \\
\hline hangianum & 26 & 4 & 2 & 2 & 2 & st & $\mathrm{t}$ & 120 \\
\hline malipoense & 26 & 2 & 2 & 2 & 1 & st & $\mathrm{t}$ & 94 \\
\hline micranthum & 26 & 4 & 2 & 2 & 2 & st & $\mathrm{t}$ & 59 \\
\hline \multicolumn{9}{|l|}{ Subg. Paphiopedilum } \\
\hline \multicolumn{9}{|l|}{ Sect. Concoloria } \\
\hline bellatulum & 26 & 2 & 2 & 2 & 0 & i & $\mathrm{t}$ & 118 \\
\hline niveum & 26 & 2 & 2 & 2 & 0 & i & $t$ & 198 \\
\hline \multicolumn{9}{|l|}{ Sect. Cochlopetalum } \\
\hline liemianum & 32 & 2 & 4 & 22 & 2 & st, i, p, c & $\mathrm{t}$ & 162 \\
\hline moquettianum & 34 & 2 & 4 & 20 & 2 & $s t, i, p, c$ & $\mathrm{t}$ & 225 \\
\hline primulinum & 32 & 2 & 4 & 25 & 2 & st, i, p, c & $t$ & 71 \\
\hline victoria-regina & 34 & 2 & 4 & 24 & 2 & st, i, p, c & $\mathrm{t}$ & 137 \\
\hline \multicolumn{9}{|l|}{ Sect. Paphiopedilum } \\
\hline druryi & 30 & 2 & 4 & 16 & 0 & st, i, p, c & $t$ & 184 \\
\hline fairrieanum & 26 & 2 & 2 & 14 & 2 & $s t, i, p, c$ & $\mathrm{t}$ & 146 \\
\hline henryanum & 26 & 2 & 2 & 17 & 2 & st, i, p, c & $\mathrm{t}$ & 180 \\
\hline hirsutissimum & 26 & 2 & 6 & 21 & 2 & st, i, p, c & t & 182 \\
\hline tigrinum & 26 & 2 & 6 & 17 & 2 & $s t, i, p, c$ & $\mathrm{t}$ & 141 \\
\hline \multicolumn{9}{|l|}{ Sect. Coryopedilum } \\
\hline adductum & 26 & 9 & 4 & 28 & 6 & st, i, p, c & t, st & 180 \\
\hline gigantifolium & 26 & 6 & 6 & 32 & 6 & st, i, p, c & $\mathrm{t}$ & 210 \\
\hline glanduliferum & 26 & 4 & 4 & 26 & 4 & st, i, p, c & $t$ & 202 \\
\hline randsii & 26 & 4 & 4 & 30 & 4 & $s t, i, p, c$ & $\mathrm{t}, \mathrm{st}$ & 187 \\
\hline sanderianum & 26 & 2 & 4 & 16 & 0 & st, i, p, c & t & 143 \\
\hline stonei & 26 & 2 & 4 & 25 & 2 & $s t, i, p, c$ & $\mathrm{t}$ & 114 \\
\hline supardii & 26 & 9 & 4 & 26 & 7 & $s t, i, p, c$ & $\mathrm{t}$ & 226 \\
\hline \multicolumn{9}{|l|}{ Sect. Pardalopetalum } \\
\hline dianthum & 26 & 2 & 4 & 28 & 2 & st, i, p, c & $t$ & 251 \\
\hline haynaldianum & 26 & 4 & 4 & 8 & 2 & st, i, p, c & t & 110 \\
\hline lowii & 26 & 6 & 4 & 28 & 4 & $s t, i, p, c$ & $\mathrm{t}, \mathrm{st}$ & 161 \\
\hline parishii & 26 & 4 & 4 & 34 & 4 & st, i, p, c & t & 189 \\
\hline \multicolumn{9}{|l|}{ Sect. Barbata } \\
\hline acmodontum & 38 & 2 & 4 & 4 & 0 & i & $\mathrm{t}$ & 169 \\
\hline curtisii & 36 & 2 & 2 & 2 & 0 & i & $\mathrm{t}$ & 164 \\
\hline dayanum & 36 & 2 & 4 & 6 & 0 & $i, p$ & $t$ & 169 \\
\hline hennisianum & 34 & 2 & 2 & 6 & 0 & i & $\mathrm{t}$ & 153 \\
\hline purpuratum & 40 & 2 & 4 & 8 & 0 & st, i & $\mathrm{t}$ & 138 \\
\hline sangii & 38 & 2 & 4 & 18 & 0 & st, i & $\mathrm{t}$ & 118 \\
\hline sukhakulii & 40 & 2 & 2 & 13 & 0 & st, i & t & 151 \\
\hline venustum & 40 & 2 & 4 & 8 & 2 & i & $\mathrm{t}$ & 109 \\
\hline wardii & 42 & 2 & 4 & 4 & 0 & $\mathrm{i}$ & t & 159 \\
\hline
\end{tabular}

\footnotetext{
${ }^{a}$ Minimum numbers of visible $5 S$ rDNA FISH signals, including numbers of both major and visible dispersed sites.
}

${ }^{b}$ st, subtelomeric; $t$, telomeric; i, interstitial; $p$, pericentromeric; c, centromeric 

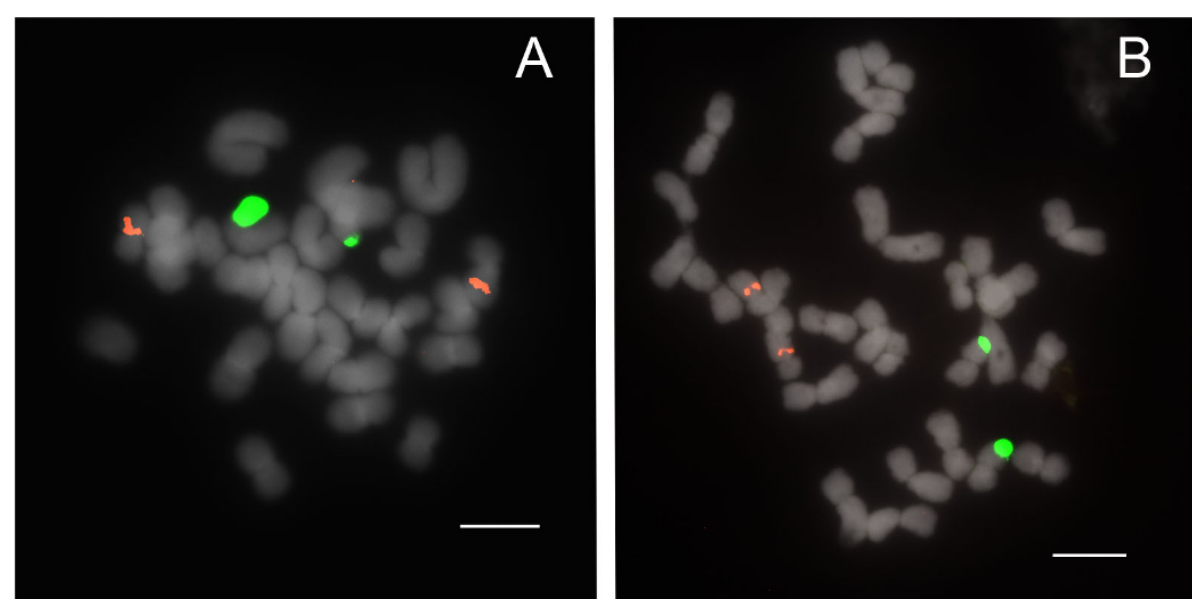

Figure 3 FISH of 25 S and 5S rDNA to metaphase chromosomes of Paphiopedilum section Concoloria. (A) Paphiopedilum bellatulum, (B) P. niveum.
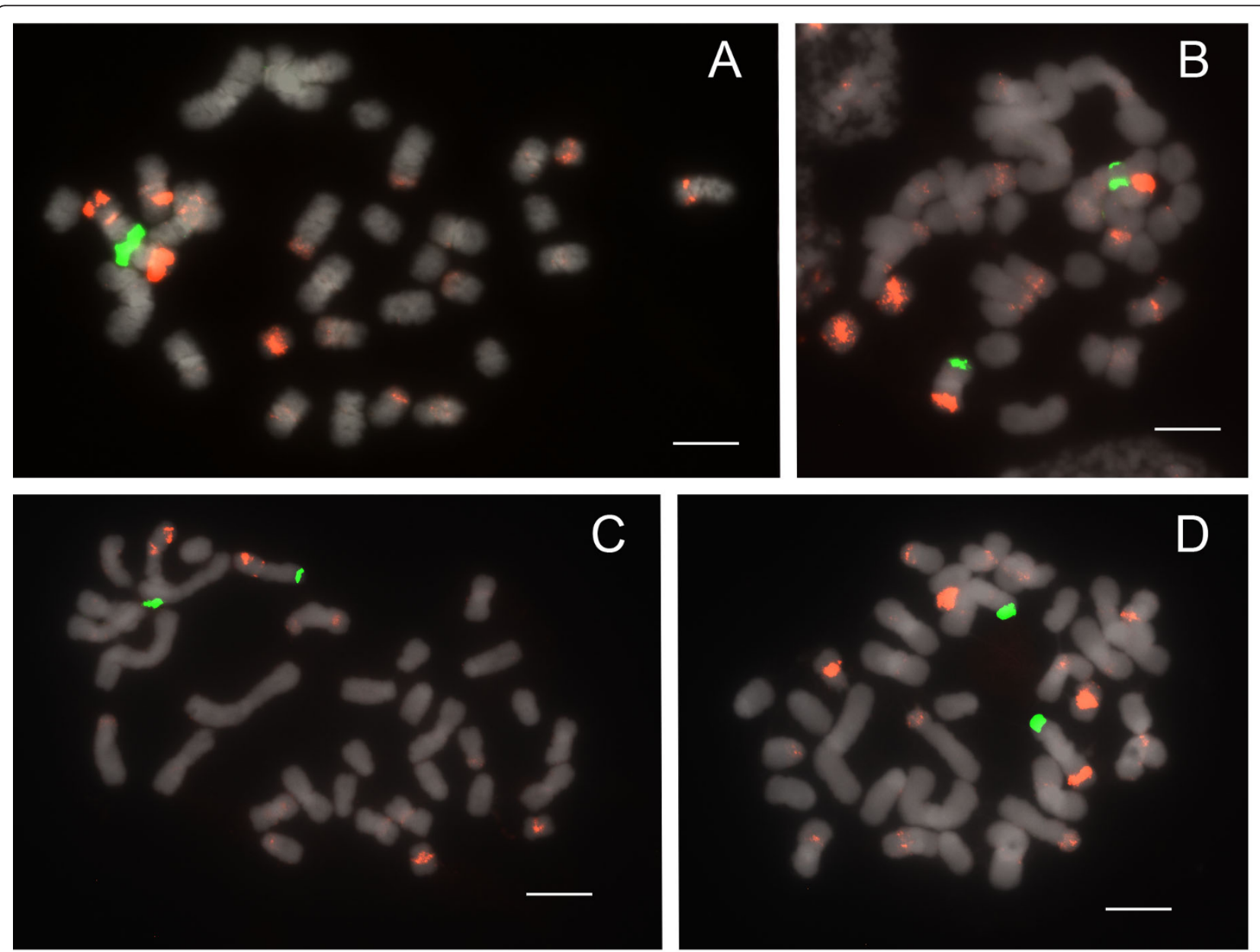

Figure 4 FISH of 25S and 5S rDNA to metaphase chromosomes of Paphiopedilum section Cochlopetalum. (A) Paphiopedilum primulinum, (B) $P$. moquettianum, (C) P. liemianum, (D) P. victoria-regina. 
same chromosome in the $2 \mathrm{n}=34$ species $P$. moquettianum (Figure 4B) and P. victoria-regina (Figure 4D).

\section{Section Paphiopedilum}

All 5 species of section Paphiopedilum studied show two $25 \mathrm{~S}$ signals in the telomeric region (Figure 5; Table 1). All species, which are $2 \mathrm{n}=26$ except for $P$. druryi (Figure $5 \mathrm{E}$ ) at $2 \mathrm{n}=30$, show at least 2 specific $5 \mathrm{~S}$ rDNA bands, as many as 6 , and numerous dispersed signals in the pericentromeric and centromeric regions. In all but $P$. druryi the major signals are closely linked with the $25 \mathrm{~S}$ arrays. In P. druryi, 4 of the major signals appear to be located on different arms and on morphologically different chromosomes that may only be partly homologous (this condition was observed in at least 4 cells).

\section{Sections Coryopedilum and Pardalopetalum}

In current phylogenetic results, section Pardalopetalum is derived within section Coryopedilum (Figure 1); as such, they will be discussed together here. Together, the Coryopedilum/Pardalopetalum clade, all species having $2 \mathrm{n}=26$, is the most dynamic in Paphiopedilum regarding chromosomal rearrangements (Figure 6, 7; Table 1). 25S signals vary from 2 to 9 , the latter showing hemizygosity. Signals in all species except Paphiopedilum lowii (Figure 7A), $P$. adductum (Figure 6E) and $P$. randsii (Figure 6F) are telomeric. 1-4 subtelomeric 25S signals were observed in P. lowii, P. adductum and P. randsii. In P. supardii (Figure 6G), one hemizygous chromosome has telomeric $25 \mathrm{~S}$ signals on each arm. P. adductum also shows $25 \mathrm{~S}$ hemizygosity, and both this species and P. supardii show the maximum number of signals. Species of the Coryopedilum/Pardalopetalum group show at least 4 major $5 \mathrm{~S}$ rDNA signals (up to 8 in P. parishii (Figure 7B)) and multiple dispersed repeats in pericentromeric and centromeric regions. In the Pardalopetalum group, all species show at least 2 strong (up to 5) 5S bands located on one chromosome. Close linkage with $25 \mathrm{~S}$ occurs throughout the group, other than in P. sanderianum (Figure 6A), either with major or minor $5 \mathrm{~S}$ bands, and appearing in different placements along chromosome arms.

\section{Section Barbata}

Species of section Barbata, which have $2 \mathrm{n}=28-42$ and the largest genome sizes, show constancy in 25S rDNA distribution, with 2 telomeric signals (Figure 8; Table 1). Major $5 \mathrm{~S}$ signals number 2-4, and extremely few dispersed
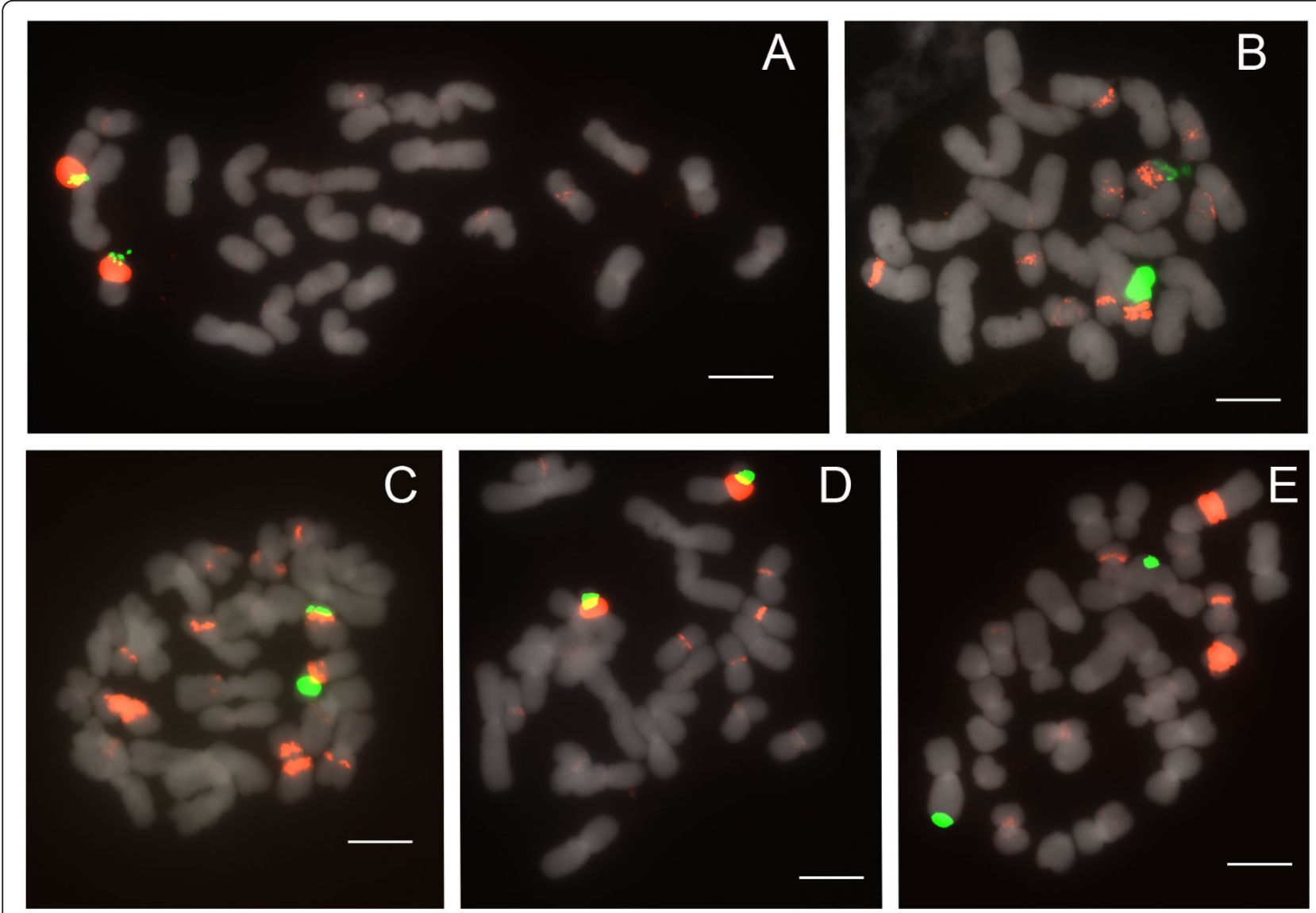

Figure 5 FISH of $25 \mathrm{~S}$ and $5 \mathrm{~S}$ rDNA to metaphase chromosomes of Paphiopedilum section Paphiopedilum. (A) Paphiopedilum fairrieanum (B) P. hirsutissimum, (C) P. tigrinum, (D) P. henryanum, (E) P. druryi. 

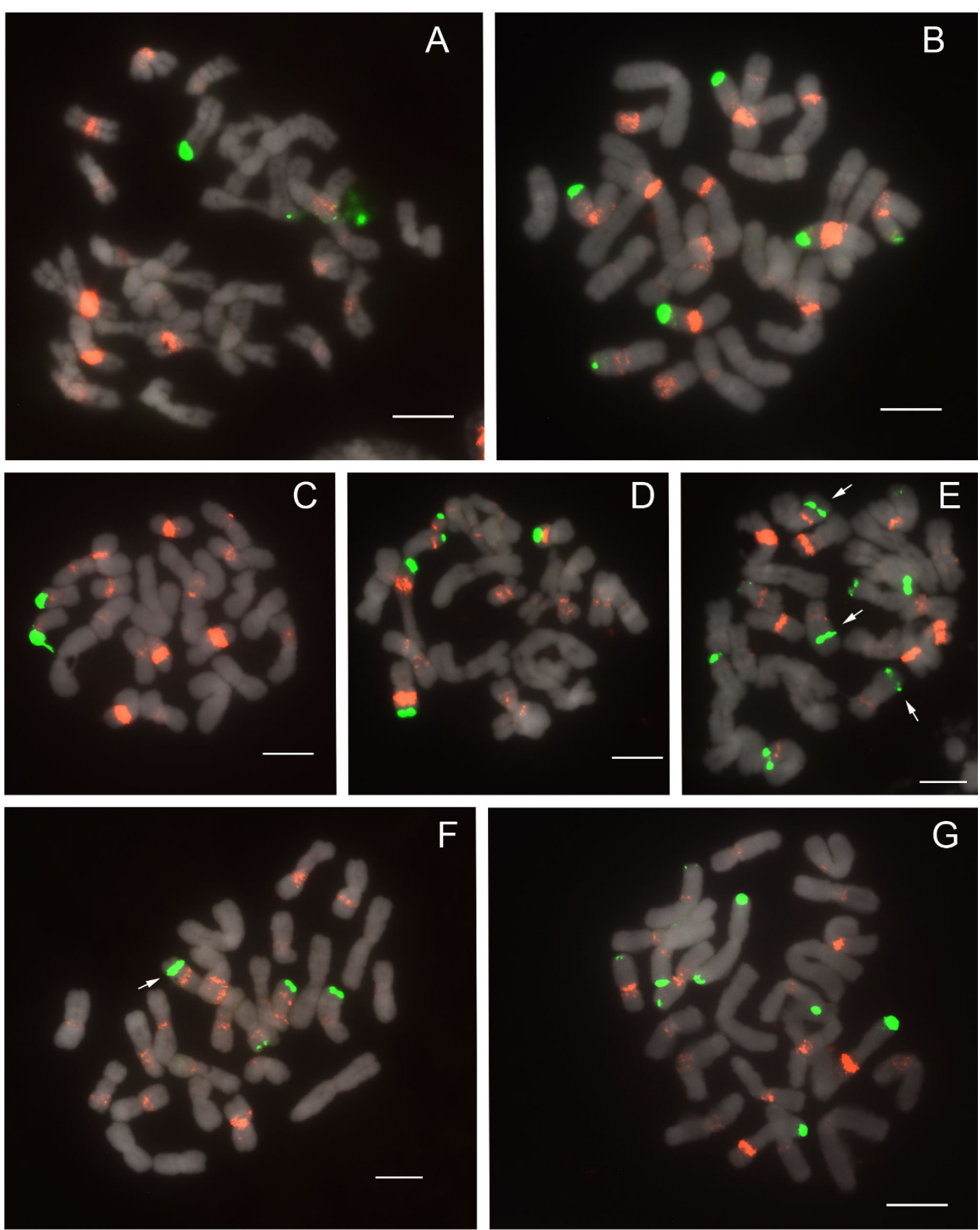

Figure 6 FISH of $25 \mathrm{~S}$ and $5 \mathrm{~S}$ rDNA to metaphase chromosomes of Paphiopedilum section Coryopedilum. (A) Paphiopedilum sanderianum, (B) P. gigantifolium, (C) P. stonei, (D) P. glanduliferum, (E) P. adductum, (F) P. randsii, (G) P. supardii. Arrows indicate subtelomeric 255 rDNA signals.

repeats were observed. Most $5 \mathrm{~S}$ loci are not centromeric, whereas telomeric, subtelomeric, pericentromeric, and interstitial placements are observed. Only Paphiopedilum curtisii (Figure 8G) and P. hennisianum (Figure 8B) have two major $5 \mathrm{~S}$ signals, and the first species shows no dispersed repeats. P. sukhakulii (Figure 8C), P. venustum
(Figure $8 \mathrm{~F}$ ) and $P$. wardii (Figure $8 \mathrm{~A}$ ) show linked $5 \mathrm{~S}$ signals. Only in $P$. venustum is close linkage of $25 \mathrm{~S}$ and $5 \mathrm{~S}$ observed, and then only involving a minor $5 \mathrm{~S}$ band. Because Barbata is the most derived section in the genus (Figure 1), either its species have lost 25S and 5S rDNA loci, since Cochlopetalum, Paphiopedilum, Coryopedilum, 

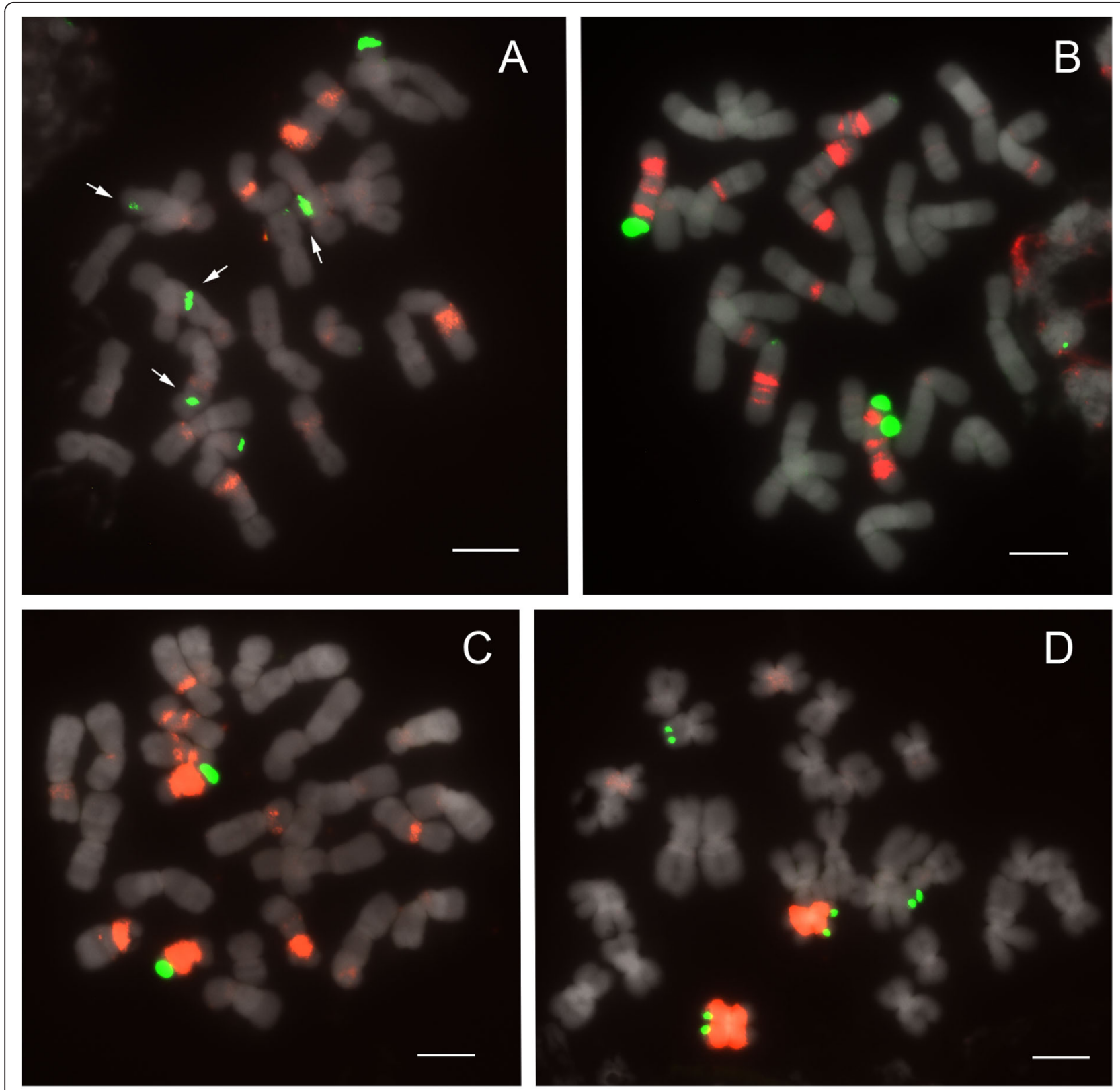

Figure 7 FISH of 25 S and 5S rDNA to metaphase chromosomes of Paphiopedilum section Pardalopetalum. (A) Paphiopedilum lowii, (B) P. parishii, (C) P. dianthum, (D) P. haynaldianum. Arrows indicate subtelomeric 255 rDNA signals.

and Pardalopetalum usually have more, or the species of the latter sections have increased the number of rDNA loci independently given the low number in sections Parvisepalum and Concoloria.

\section{Diversity of 5S ribosomal DNA non-transcribed spacer sequences}

We investigated duplication history correlated with the dynamic rearrangements observed in $5 \mathrm{~S}$ rDNA loci. In order to survey sequence variation in 5S-NTS, random clones, 7 (Paphiopedilum niveum) or 8 (all others) per species, were sequenced (Additional file 1). Only a few clones were identical to each other (2 sequences from P. acmodontum, 2 from $P$. henryanum, 2 from $P$. hirsutissimum, 2 from $P$. stonei, 4 from $P$. dayanum, 4 from $P$. malipoense, and one sequence each of $P$. stone $i$ and $P$. supardii). Sequences of 5S-NTS ranged from $283 \mathrm{bp}$ (P. micranthum 1) to $455 \mathrm{bp}$ ( $P$. bellatulum 5$)$. Given extensive sequence divergence of 5S-NTS and our desire not to manually adjust alignment [24], an objective alignment was accomplished using MAFFT and default settings. Numbers of polymorphic loci within species, and 

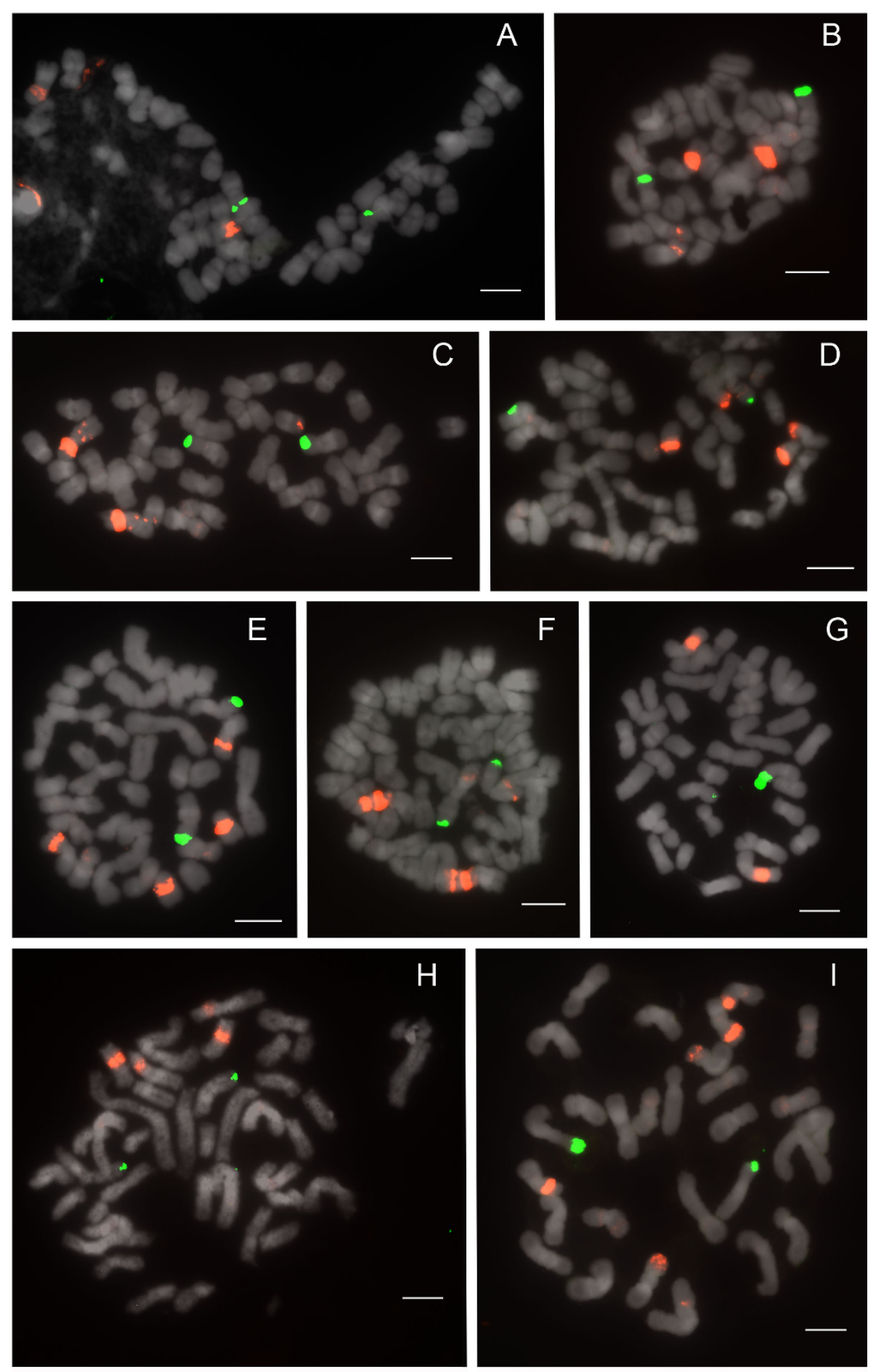

Figure 8 FISH distribution pattern of $25 \mathrm{~S}$ and $5 \mathrm{~S}$ rDNA on metaphase chromosomes of Paphiopedilum section Barbata. (A) Paphiopedilum wardii, (B) P. hennisianum, (C) P. sukhakulii, (D) P. purpuratum, (E) P. dayanum, (F) P. venustum, (G) P. curtisii, (H) P. acmodontum, (I) P. sangii.

phylogenetic relationships, were assessed in order to estimate the strength of gene conversion and the extent of paralogy, respectively. Numbers of polymorphic sites within species positively correlated with minimum numbers of visible 5 S signals $\left(P<0.01, R^{\wedge} 2=0.21\right.$; Figure 9$)$, suggesting that interlocus gene conversion is relatively weak. A phylogenetic tree outgroup-rooted using Phragmipedium besseae showed 2 major groups of sequences: section Parvisepalum 


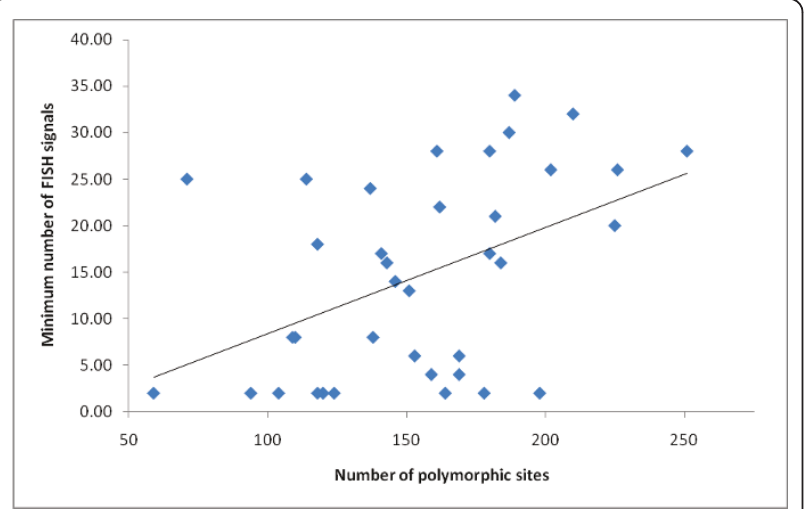

Figure 9 The relationship between polymorphism of 5S-NTS sequences and numbers of observed 5S rDNA signals. Line indicates trend derived from linear regression analysis based on 5SNTS within-species polymorphic sites and minimum numbers of visible $5 S$ signals (data from Table 1.). $P<0.01, R \wedge 2=0.21$.

versus the remainder of the genus. The single tree of maximum likelihood is shown (as a phylogram, Additional file 2), as is the majority-rule consensus tree based on 100 bootstrap replicates (Additional file 3). Some large species-specific clades were observed, as well as some sectionspecific clades. Overall, however, the phylogenetic tree was poorly representative of phylogenetic relationships due to extensive duplication of $5 \mathrm{~S}$ loci.

\section{Discussion}

Variation in numbers and chromosomal locations of rDNA Variation in numbers and distribution patterns of rDNA loci among related species is commonly observed in many different plant genera, including Brassicaceae [10], Cyperaceae [11], Asteraceae [25,26], Leguminosae [27], Pinus [28], and Rosaceae [14]. Plants typically show some degree of conservatism of rDNA repeat duplication, such that when multiple loci do appear, species are commonly polyploid relatives of diploids. There is no evidence at all, however, for polyploidy in Paphiopedilum, where the only chromosome number differences are aneuploid, in a series reflective of centric fission or fusion.

In general, FISH patterns of $25 \mathrm{~S}$ rDNA loci are reported to be more polymorphic than those of the $5 \mathrm{~S}$ rDNA [12-14,26,28-32]. Conversely, in all sections of Paphiopedilum, except for Parvisepalum and Concoloria, $5 \mathrm{~S}$ rDNA sites showed much more variability both in number and physical location than did 25S rDNA sites.

The most parsimonious ancestral number of $25 \mathrm{~S}$ rDNA sites in Paphiopedilum is two, based on outgroup comparison to the genera Mexipedium and Phragmipedium (unpublished results; [3,22]). Duplication of $25 \mathrm{~S}$ rDNA sites was observed only in three of the seven sections of Paphiopedilum: Parvisepalum $(2 \mathrm{n}=26)$,
Coryopedilum $(2 \mathrm{n}=26)$ and Pardalopetalum $(2 \mathrm{n}=26)$ (Table 1). The physical positions of $25 \mathrm{~S}$ rDNA loci are relatively conservative. In most Paphiopedilum species we analyzed, $25 \mathrm{~S}$ rDNA signals are located in terminal chromosome positions. Variation was only observed in three species, Paphiopedilum adductum, P. randsii and P. lowii, which showed 1-4 subtelomeric 25S rDNA signals (Figures 6E, F and 7A, respectively). The ancestral number of $5 \mathrm{~S}$ rDNA sites, again by outgroup comparison, is 2 (unpublished results from Mexipedium and Phragmipedium), and is only observed in sections Parvisepalum and Concoloria. Massive duplication and amplification of $5 \mathrm{~S}$ rDNA loci, leading to large-scale polymorphism of numbers, sizes and physical positions of signals, was found prevalent in the remaining five sections. The numbers and distribution of rDNA loci vary widely among plants; however, usually less than one-third of chromosomes display either $45 \mathrm{~S}$ rDNA or $5 \mathrm{~S}$ rDNA [13]. It is therefore noteworthy that in some lineages of Paphiopedilum, up to 24 of the 26 chromosomes bear at least one rDNA locus, and a single chromosome can bear up to five major $5 \mathrm{~S}$ rDNA loci.

Apparently, there is no strong correlation between the increase in the number of rDNA sites and the increase in the number of chromosomes or genome size. A similar situation has also been described in many other diploid species, e.g. the diploid lineage of Brassicaceae [10], Cyperaceae [11,12], Iris [13], and Rosaceae [14]. The massive duplication of rDNA loci in Paphiopedilum sections Cochlopetalum, Paphiopedilum, Coryopedilum and Pardalopetalum could partly contribute to the increase of genome size. Perhaps paradoxically, species with the smallest (P. exul; section Paphiopedilum) and largest (P. dianthum; section Pardalopetalum) haploid genome sizes are both members of groups that show considerable $25 \mathrm{~S}$ and $5 \mathrm{~S}$ locus duplication in our FISH experiments. These two species differ more than two-fold in genome size, 16.1 to $35.1 \mathrm{Mb}$, respectively [33]. If we assume that the number of distinct genes among Paphiopedilum species is roughly constant, this would suggest that genome size increase is primarily due to repetitive element amplification, but that since rDNA duplication is associated with both smaller and larger genomes in the genus, size differences may be more logically traceable to other repetitive DNAs, such as mobile elements. However, a possible tendency for elimination of rDNA loci was found in section Barbata, which has the greatest average genome sizes and chromosome numbers [4]. The number of $25 \mathrm{~S}$ rDNA loci in Barbata remains two through all the species we studied, while the distribution pattern of $5 \mathrm{~S}$ rDNA is less dispersed than its sister group, Coryopedilum plus Pardalopetalum. Due to the derived phylogenetic position of section Barbata (Figure 1), it is most parsimonious to conclude that unique chromosomal 
conditions seen in the group would be similarly derived (autapomorphic). As such, centric fission in Barbata appears to be associated with loss of rDNA loci, while in other systems, centric fission has led to rDNA gains [34]. Elimination of rDNA loci during chromosomal evolution has been documented in, e.g., Brassicaceae and Rosaceae $[10,14]$. The mechanism that accounts for such loss of rDNA loci, however, remains unclear. A presumed evolutionary loss of abundant terminal nucleolar organizing regions (NOR) in Arabidopsis has been hypothesized to be the consequence of an ancient fusion event [35]. In the case of section Barbata, additional traceable chromosome markers are needed to provide further evidence that chromosomal rearrangements are related to rDNA loss.

\section{A combination of different mechanisms causes high mobility of rDNA}

Different mechanisms have been postulated to account for the mobility and polymorphism of numbers, sizes and positions of rDNA sites, such as transposon-mediated transpositional events [36-38], and chromosome rearrangements (translocation, inversion, duplication, deletion) caused by homologous or non-homologous unequal crossing-over and gene conversion $[9,28,30,36]$. These processes could act alone or in combination, and they do not necessarily imply changes in overall chromosome morphology [31,34].

The great degree of $5 \mathrm{~S}$ repeat dispersion seen in sections Cochlopetalum, Paphiopedilum, Coryopedilum and Pardalopetalum has, to our knowledge, only been observed in the monocots Alstroemeria, Tulipa, and Iris [13,39,40]. The original seeding of rDNA repeats to ectopic locations in the genome could be the result of transposable element activity or perhaps incorporation of array segments into breakpoints as part of non-homologous end joining during DNA repair. Indeed, some of the signals we observed may be pseudogenes transported within the genomes by retroelements, therefore leading to the false interpretation that we are visualizing entire and active rDNA arrays. Both subtelomeric and pericentromeric regions are well known as hot spots of breakpoints and are also enriched for TEs $[5,6]$. Considering the abundant minor loci we observed in these regions, a contribution of transpositions to the dispersed distribution pattern is tenable, and TEs containing $5 \mathrm{~S}$ rDNA-derived sequences have in fact been observed in many plants [41] and animals [42]. It is nonetheless possible that due to the similarity of rDNA arrays, chromosomal rearrangement could be induced via heterologous recombination, and in turn, rearrangement could generate repeated sequences through unequal crossovers. After generation of a novel locus, in situ amplification cycles via rearrangement could lead to the origin of FISH-detectable loci. Furthermore, hemizygous 5S rDNA sites have been widely observed in many Paphiopedilum species. A double-strand break occurring in a hemizygous region would increase the probability of causing other rearrangements, owing to the absence of a homologous template for its repair [5]. The lack of dispersed repeats in the basalmost section Parvisepalum may reflect either a lack of seeding events or slow amplification processes that do not yield hybridization-visible arrays. However, in the case of $5 \mathrm{~S}$ rDNA, there is in fact strong evidence for NTS sequence diversity, which could either be accounted for by the presence or small loci below the FISH detection limit or perhaps by considerable within-array diversity. One future experimental approach to determine whether considerable intra-array diversity indeed exists would be to perform FISH using 5S-NTS-specific probes.

Diversification of $25 \mathrm{~S}$ rDNA distribution patterns is also observed in Paphiopedilum, but the numbers of loci and degree of dispersion is much lower than for $5 \mathrm{~S}$ rDNA. Therefore, $5 \mathrm{~S}$ rDNA might be more frequently seeded by TEs via transpositional events, or, amplification or maintenance of $5 \mathrm{~S}$ rDNA loci via rearrangement could be more effective and tolerated during the chromosome evolution process. The different evolutionary tendencies between $25 \mathrm{~S}$ and $5 \mathrm{~S}$ rDNA might be caused by their function and sequence divergence or localization in distinct nuclear compartments [43].

\section{S-NTS sequences highlight interlocus and intralocus diversity and weak concerted evolutionary forces}

Previous studies of other angiosperm species have suggested that intralocus $5 \mathrm{~S}$ rDNA diversity occurs. Withinarray 5S rDNA diversity appears very likely in Paphiopedilum as well, since many species (e.g., all Parvisepalum and Concoloria) have only one observable $5 \mathrm{~S}$ locus. For example, 6 species of section Parvisepalum are represented in our phylogenetic analysis by 6-8 distinct sequence variants. These 5S-NTS variants can be concluded to occur within at least partial arrays, pseudogenized or not, since the amplified pieces include sections of 5S rDNA at their 5' and 3' ends. Recent within-species duplication events may be indicated by single-species clades of 5S-NTS sequences, such as $P$. dayanum, $P$. lowii, $P$. sangii, but these could just as well indicate within-array variation, as single-species clades of Parvisepalum (e.g., P. malipoense) and Concoloria ( $P$. bellatulum) most likely do. In many cases, it can be readily seen that duplication of $5 \mathrm{~S}$ loci has occurred prior to speciation, for example, within Coryopedilum (a large group of sequences representing $P$. sanderianum, P. stonei, and P. supardii; similarly also within a group of $P$. adductum and $P$. randsii sequences). In some cases, ancient duplications must be much older than the major phylogenetic groups of Paphiopedilum, since, for example, $P$. delenatii shares sequence variants similar to other Parvisepalum species yet has at least one other variant 
that is more similar to sequences from all other sections. We investigated the possibility of contamination regarding this finding, but discovered similar repeats across 8 distinct $P$. delenatii accessions (results not shown). Another explanation for multispecies clades, e.g., within well-defined groups such as Parvisepalum could be ancient hybridization.

We observed that increasing within-species 5S NTS sequence diversity correlates with increasing minimum numbers of visible 5S rDNA loci in Paphiopedilum (Figure 9); therefore we infer that interlocus concerted evolution is weak within the genus. Our conclusion concurs with previous findings in many plant genera, such as Gossypium [17], Triticum [18], Chenopodium [19], Nicotiana [20] and Pinus [27]. So far, to our knowledge, noticeable interlocus concerted evolution of $5 \mathrm{~S}$ rDNA arrays has not been demonstrated in plants.

The best supported hypothesis to explain weak homogenization forces on $5 \mathrm{~S}$ rDNA arrays is that the chromosomal location of rDNA arrays has a substantial impact on interlocus concerted evolution [17,20,44-47]. Arrays located in subtelomeric regions are thought to undergo stronger interlocus homogenization forces than ones located in proximal regions. Potential evidence was observed in section Barbata, in which all of six species studied possess two $5 \mathrm{~S}$ loci. These six species can be categorized into two groups according to the locations of $5 \mathrm{~S}$ loci. One group harboring proximal $5 \mathrm{~S}$ loci includes $P$. wardii, $P$. dayanum, $P$. venustum and $P$. acmodontum, while the other group harboring subtelomeric $5 \mathrm{~S}$ loci includes P. purpuratum and P. sangii (Figure 8; Table 1). Considering that all six species are closely related and possess the same number of loci, it can be logically assumed that the difference in sequence polymorphism between the two groups is caused by the different locations of the $5 \mathrm{~S}$ loci. The fact that the average number of polymorphic sites in the proximal-loci group (151.5) is $18 \%$ more than that in the subtelomeric-loci group (128), indicates that proximally located loci seem less homogenized than the subtelomerically located loci.

Additionally, we found that not only interlocus but also intralocus concerted evolution is also influenced by chromosomal localization. In section Concoloria, two closely related species, $P$. bellatulum and $P$. niveum, both have one $5 \mathrm{~S}$ locus, but with different localizations. The difference in sequence polymorphism between the two species may be caused by the different locations of the $5 \mathrm{~S}$ loci. $P$. niveum, which has a pericentromeric locus, showed 1.68 - fold more polymorphic sites than P. bellatulum, which has a subtelomeric locus (Table 1).

It is well-known that meiotic homologous recombination has been largely suppressed in pericentromeric and centromeric regions. Unequal crossovers between sister chromatids and gene conversion documented in the centromeres of many organisms have been postulated as the major homogenization force for tandem repeats located in these areas [48-52]. A plausible explanation for this has been proposed previously: if unequal crossover events between rDNAs of two chromosomes occurred in the proximal region to centromeres, this may result in the exchange of not only a fraction of the rDNA but also the centromeres themselves. Such an event is more likely to have significantly greater negative consequences to the organism than if the event occurred in the subtelomeric region, which then might result in exchange of telomeres $[17,47]$; loss of centromeres would prohibit cell division, whereas loss of telomeres might not restrict mitosis or meiosis. As such, centromerically-located rDNA arrays are expected to show weaker homogenization forces, since fewer individuals with unequal crossovers in this region are expected to survive. In contrast, the subtelomeric region is characterized by a higher rate of interchromosomal exchange [5], thus stronger concerted evolutionary forces could be expected in this region.

All species of section Parvisepalum, as with P. bellatulum, have subtelomeric $5 \mathrm{~S}$ loci, some of which are closely linked with $25 \mathrm{~S}$ loci. If $5 \mathrm{~S}$ localization correlates significantly with homogenization, as with $25 \mathrm{~S}$, which is always telomeric-subtelomerically located, we should expect subtelomeric $5 \mathrm{~S}$ repeats to show decreased sequence diversity due to stronger concerted evolutionary forces. However, this is not the case, since variation in the number of polymorphic sites is not significantly different by section (with or without Pardalopetalum included in Coryopedilum; single factor ANOVA $P=0.06$ and 0.1 , respectively). We therefore infer that localization of the $5 \mathrm{~S}$ rDNA arrays only partially contributes to the weak concerted evolution observed in Paphiopedilum.

There are several other hypothesized mechanisms that could lead to the weak concerted evolutionary force on $5 \mathrm{~S}$ rDNA arrays. For example, ongoing chromosomal rearrangement such as insertion, deletion, or transposition could occur within arrays too frequently for interlocus concerted evolution to be effective. Another possibility is that concerted evolutionary processes homogenize $5 \mathrm{~S}$ rDNA arrays at rates lower than the rate of speciation, thus novel mutations cannot be fixed or removed and high levels of intralocus polymorphism are expected within arrays [17]. Additionally, the base composition and secondary structure of rDNA sequences may also affect the rate of concerted evolution [53]. It is unknown whether weak concerted evolutionary forces are shared by other Paphiopedilum tandem repeats, or if this is characteristic of $5 \mathrm{~S} \mathrm{rDNA}$ arrays only. This issue can be elucidated by further studies on other tandem repeats, such as $25 \mathrm{~S}$ rDNA arrays. 


\section{Conclusions}

Paphiopedilum species display many chromosomal rearrangements - for example, duplications, translocations, and inversions - but only weak concerted evolutionary forces among highly duplicated $5 \mathrm{~S}$ arrays, which suggests that double-strand break repair processes are dynamic and ongoing. These results make the genus a model system for the study of complex chromosomal evolution in plants.

\section{Methods}

\section{Plant materials}

Thirty-seven species of the Paphiopedilum genus covering all seven sections were analyzed in this study. Information on the species and sections is provided in Table 1. Actively growing roots were used for chromosome preparation, while leaves were used for genomic DNA extraction.

\section{Chromosome preparation}

Root tips were pre-treated with $0.004 \mathrm{M}$ 8-hydroxyquinoline for 4-6 $\mathrm{h}$ at $10^{\circ} \mathrm{C}$, and fixed in freshly prepared fixative (3:1 ethanol: acetic acid) for $48 \mathrm{~h}$ at $10^{\circ} \mathrm{C}$. The fixed root tips were then rinsed thoroughly with tap water and macerated in an enzyme mixture containing $2 \%$ cellulase (Onozuka R-10, Rpi) and 1\% pectolyase (Aspergillus japonicus $\mathrm{Y}-23, \mathrm{MP})$ at $37^{\circ} \mathrm{C}$ for $30 \mathrm{~min}$. After re-fixation in fixative for $15 \mathrm{~min}$, the meristematic cells were squashed in a drop of $45 \%$ acetic acid under a coverslip $(22 \times$ $22 \mathrm{~mm}$ ) on a microscope slide. Slides were then dipped into liquid nitrogen and air dried after the coverslips were carefully removed by a blade.

Probe labelling and Fluorescence in situ hybridization (FISH) $25 \mathrm{~S}$ rDNA, a 2.3-kb ClaI subclones of the 25S rDNA coding region of Arabidopsis thaliana [54] and 5S rDNA (pTa794) [55]were used as probes. 25S rDNA was labelled with biotin-16-dUTP (Roche) and 5S rDNA was labelled with digoxigenin-11-dUTP (Roche), all by nick translation method using the kit from Roche. The hybridization buffer consisted of $50 \%$ deionized formamide, $2 \times$ SSC, $50 \mathrm{mM}$ sodium phosphate (pH 7.0), 10\% dextran sulfate and sheared salmon sperm DNA (Invitrogen) in $100 \times$ excess of labeled probes. The $25 \mathrm{~S}$ and $5 \mathrm{~S}$ rDNA probes were mixed to a final concentration of about $2 \mathrm{ng} / \mu \mathrm{l}$ and then denatured at $94^{\circ} \mathrm{C}$ for $10 \mathrm{~min}$ before being used. Slides with metaphase spreads were treated with $70 \%$ deionized formamide in $2 \times \mathrm{SSC}$ at $70^{\circ} \mathrm{C}$ for $2 \mathrm{~min}$. Denatured probes in hybridization buffer were then applied to the slides, which were incubated at $37^{\circ} \mathrm{C}$ for $10 \mathrm{~h}$ in a humid chamber. Post-hybridization washes and immunodetection were carried out in an automated in situ hybridization instrument, the InsituPro VSi (Intavis Bionanalytical Instruments). The slides were washed in $2 \times \mathrm{SSC}$ at room temperature for $5 \mathrm{~min}$ and twice in $2 \times \mathrm{SSC}$ at $50^{\circ} \mathrm{C}$ for
$10 \mathrm{~min}$. Fluorescence signal was detected using antiDigoxigenin-Rhodamine conjugate (Roche) and streptavidin-fluorescein conjugate (Invitrogen). The preparations were mounted and counterstained in Vectashield containing $1.5 \mu \mathrm{g} / \mathrm{ml}$ DAPI (4', 6-diamidino-2-phenylindole) (Vector Laboratories). Images were taken by a Zeiss AxioCam MRm black-and-white CCD camera on a Zeiss Imager. Z1 fluorescence microscope and then processed uniformly using Zeiss AxioVision software. FISH signals were false-colored, and DAPI fluorescence was left in gray-tone.

\section{PCR amplification, cloning and sequencing}

Total genomic DNA was extracted from fresh leaves using Qiagen DNeasy Plant Mini kit. The 5S-NTS region was amplified by PCR using the universal degenerate primers: 5'-TGGGAAGTCCTYGTGTTGCA-3' and 5'-KTMGYGC TGGTATGATCGCA-3' [56]. Touchdown amplification was performed as follows: an initial step at $94^{\circ} \mathrm{C}$ for $5 \mathrm{~min}$, followed by 10 cycles of $94^{\circ} \mathrm{C}$ for $1 \mathrm{~min}$, annealing for $1 \mathrm{~min}$ (start at $60^{\circ} \mathrm{C}$, and decreased by $1^{\circ} \mathrm{C}$ per cycle), and $72^{\circ} \mathrm{C}$ for $1 \mathrm{~min}$, then 35 cycles of $94^{\circ} \mathrm{C}$ for $1 \mathrm{~min}, 50^{\circ} \mathrm{C}$ for $1 \mathrm{~min}$, and $72^{\circ} \mathrm{C}$ for $1 \mathrm{~min}$, the final step at $72^{\circ} \mathrm{C}$ was extended to $10 \mathrm{~min}$. After gel purification using QIAquick Gel Extraction Kit (Qiagen), PCR products were ligated into pDrive Cloning vector and transformed into QIAGEN EZ competent cells (Qiagen PCR Cloning kit). Recombinant clones were screened by colony direct PCR method and were sequenced 7-8 clones per each species using $\mathrm{T} 7$ (5'-TAATACGACTCACTATAGGG-3') primer.

\section{Data analysis}

Sequences were aligned using the MAFFT (Multiple Alignment using Fast Fourier Transform) web server at the European Bioinformatics Institute [57]. Default parameters were used: gap opening penalty $=1.53$, gap extension penalty $=0.123$, tree rebuilding number $=1$, maxiterate $=0$, and perform FFTS $=$ localpair. The sequence alignment is available as a supplementary FASTA file (Additional file 4).

Within-species 5S-NTS polymorphism was estimated, based on the aforementioned multiple alignment, using DnaSP version 5.10.01 [58]. The relationship between numbers of polymorphic sites and minimum numbers of visible $5 \mathrm{~S}$ rDNA signals was investigated using linear regression analysis (in Microsoft Excel).

Phylogenetic reconstruction was performed using maximum likelihood optimization available through the RaxML BlackBox web server [59] running RaxML version 7.2.8 [60]. Default settings were used. The 8 Phragmipedium besseae sequences were indicated as the outgroup. RaxML was called using the following commands: raxml -\# 100 -n pasted -o bess1, bess2, 
bess3, bess4, bess5, bess6, bess7, bess 8 -f a -m GTRGAMMA - x 564547904 -p 564547904 -s OVaDTW. All search information, as was output on the web site, is included in Additional file 5.

\section{Additional material}

Additional file 1: GenBank data deposition information of 5S-NTS
sequences

Additional file 2: 5S-NTS sequences: the single tree of maximum likelihood

Additional file 3: 5S-NTS sequences: the majority-rule consensus tree based on 100 bootstrap replications

Additional file 4: The 5S-NTS sequence alignment using MAFFT, provided in FASTA format

Additional file 5: Report from RAxML phylogenetic analysis of 5S-NTS sequences

\section{Acknowledgements}

We thank R. Hasterok and B. Liu for providing rDNA clones. This study was supported by funds from the University at Buffalo.

\section{Authors' contributions}

$T L$ and VAA conceived of the study, TL performed all experiments, $T L$ and VAA analyzed data, and both TL and VAA prepared the manuscript. All auhors read and approved the final manuscript.

Received: 1 July 2011 Accepted: 12 September 2011

Published: 12 September 2011

\section{References}

1. Cribb P: The genus Paphiopedilum. Natural History Publications. 2 edition. Borneo; 1998

2. Karasawa K: Karyomorphological studies in Paphiopedilum. Orchidaceae. Bulletin of the Hiroshima Botanic Garden 1979, 2:1-149.

3. Cox A, Pridgeon AM, Albert VA, Chase MW: Phylogenetics of the slipper orchids (Cypripedioideae, Orchidaceae). Nuclear rDNA ITS sequences Plant Syst Evol 1997, 208(3-4):197-223.

4. Cox A, Abedelnour G, Bennett MD, Leitch IJ: Genome size and karyotype evolution in the slipper orchids (Cypripedioideae: Orchidaceae). American Journal of Botany 1998, 85(5):681-687.

5. Linardopoulou E, Williams EM, Fan Y, Friedman C, Young JM, Trask BJ: Human subtelomeres are hot spots of interchromosomal recombination and segmental duplication. Nature 2005, 437(7055):94-100.

6. Slotkin R, Martienssen R: Transposable elements and the epigenetic regulation of the genome. Nat Rev Genet 2007, 8(4):272-285.

7. Zhang J: Evolution by gene duplcation: an update. Trends in Ecology and Evolution 2003, 18(6):292-298

8. Hurles M: Gene duplication: The genomic trade in spare parts. PLoS Biol 2004, 2(7):0900-0904

9. Raskina O, Barber JC, Nevo E, Belyayev A: Repetitive DNA and chromosomal rearrangements: speciation-related events in plant genomes. Cytogenet Genome Res 2008, 120(3-4):351-357.

10. Hasterok R, Wolny E, Hosiawa M, Kowalczyk M, Kulak-Ksiazczyk S, Ksiazczyk T, Heneen WK, Maluszynska J: Comparative analysis of rDNA distribution in chromosomes of various species of Brassicaceae. Annals of Botany 2006, 97(2):205-216.

11. Da Silva C, Quintas CC, Vanzela AL: Distribution of 455 and $5 S$ rDNA sites in 23 species of Eleocharis (Cyperaceae). Genetica 2010, 138(910):951-957.

12. Sousa A, Barros e Siva AE, Cuadrado A, Loarce Y, Alves MV, Guerra M: Distribution of $5 \mathrm{~S}$ and $45 \mathrm{~S}$ rDNA sites in plants with holokinetic chromosomes and the "chromosome field" hypothesis. Micron 2011, 42(6):625-631.
13. Martinez J, Vargas $P$, Luceno $M$, Cuadrado A: Evolution of Iris subgenus Xiphium based on chromosome numbers, FISH of nrDNA $(5 \mathrm{~S}, 45 \mathrm{~S})$ and trnL-trnF sequence analysis. Plant Syst Evol 2010, 289:223-235.

14. Mishima M, Ohmido N, Fukui K, Yahara T: Trends in site-number change of rDNA loci during polyploid evolution in Sanguisorba (Rosaceae). Chromosoma 2002, 110(8):550-558.

15. Lee $Y$, Chung MC: Identification of genome relationships among Paphiopedilum species by genomic and fluorescent in situ hybridization. Acta Horiticluturae 2008, 766:331-334.

16. Lee $Y$, Chang FC, Chung MC: Chromosome pairing affinities in interspecific hybrids reflect phylogenetic distances among lady's slipper orchids (Paphiopedilum). Annals of Botany 2011, 108(1):113-121.

17. Cronn R, Zhao X, Paterson AH, Wendel JF: Polymorphism and concerted evolution in a tandemly repeated gene family: $5 \mathrm{~S}$ ribosomal DNA in diploid and allopolyploid cottons. J Mol Evol 1996, 42(6):685-705

18. Kellogg $E$, Appels R: Intraspecific and interspecific variation in 5S RNA genes are decoupled in diploid wheat relatives. Genetics 1995, 140(1):325-343.

19. Maughan P, Kolano BA, Maluszynska J, Coles ND, Bonifacio A, Rojas J, Coleman CE, Stevens MR, Fairbanks DJ, Parkinson SE, Jellen EN: Molecular and cytological characterization of ribosomal RNA genes in Chenopodium quinoa and Chenopodium berlandieri. Genome 2006 49(7):825-839.

20. Fulnecek J, Lim KY, Leitch AR, Kovarík A, Matyásek R: Evolution and structure of $5 \mathrm{~S}$ rDNA loci in allotetraploid Nicotiana tabacum and its putative parental species. Heredity 2002, 88(1):19-25.

21. Liu Z, Zhang DM, Wang XQ, Ma XF, Wang XR: Intragenomic and interspecific $5 \mathrm{~S}$ rDNA sequence variation in five Asian pines. American Journal of Botany 2003, 90:17-24.

22. Albert V: Cladistic relationships of the slipper orchids (Cypripedioideae: Orchidaceae) from congruent morphological and molecular data. Lindleyana 1994, 9:115-132.

23. Anisimova M, Cannarozzi GM, Liberles DA: Finding the balance between the mathematical and biological optima in multiple sequence alignment. Trends in Evolutionary Biology 2010, 2(1):e7.

24. Garcia S, Panero JL, Siroky J, Kovarik A: Repeated reunions and splits freature the highly dynamic evolution of $5 \mathrm{~S}$ and $35 \mathrm{~S}$ ribosomal RNA genes (rDNA) in the Asteraceae family. BMC Plant Biology 2010, 10:176.

25. Malinska H, Tate JA, Matyasek R, Leitch AR, Soltis DE, Soltis PS, Kovarik A Similar patterns of rDNA evolution in synthetic and recently formed natural populations of Tragopogon (Asteraceae) allotetraploids. BMC Evolutionary Biology 2010, 10:291.

26. Moscone E, Klein F, Lambrow M, Fuchs J, Schweizer D: Quantitative karyotyping and dual-color FISH mapping of 5S and 18S-25S rDNA probes in the cultivated Phaseolus species (Leguminosae). Genome 1999, 42(6):1224-1233.

27. Cai Q, Zhang D, Liu Z-L, Wang X-R: Chromosomal localization of 5 S and $18 \mathrm{~S}$ rDNA in five species of subgenus Strobus and their implications for genome evolution of Pinus. Annals of Botany 2006, 97(5):715-722.

28. Hanson R, Islam-Faridi MN, Percival EA, Crane CF, Ji Y, McKnight TD, Stelly DM, Price HJ: Distribution of 5 S and 18S-28S rDNA loci in a tetraploid cotton (Gossypium hirsutum $\mathrm{L}$ ) and its putative diploid ancestors. Chromosoma 1996, 105(1):55-61.

29. Linares C, Gonzalez J, Ferrer E, Fominaya A: The use of double fluorescence in situ hybridization to physically map the positions of $5 \mathrm{~S}$ rDNA genes in relation to the chromosomal location of 18S-5. 8S-26S rDNA and a $C$ genome specific DNA sequence in the genus Avena. Genome 1996, 39(3):535-542.

30. Thomas H, Harper JA, Meredith MR, Morgan WG, Thomas ID, Timms E, King IP: Comparison of ribosomal DNA sites in Lolium species by fluorescence in situ hybridization. Chromosome Research 1996, 4(7):486-490.

31. Datson P, Murray BG: Ribosomal DNA locus evolution in Nemesia: transposition rather than structural rearrangement as the key mechanism? Chromosome Research 2006, 14(8):845-857.

32. Ksiazczyk T, Taciak M, Zwierzykowski Z: Variability of ribosomal DNA sites in Festuca pratensis, Lolium perenne, and their intergeneric hybrids, revealed by FISH and GISH. J App/ Genet 2010, 51(4):449-460.

33. Plant DNA C-values database (release 5.0, Dec. 2010). [http://www.kew. org/cvalues/]. 
34. Hall K, Parker JS: Stable chromosome fission associated with rDNA mobility. Chromosome Research 1995, 3(7):417-422

35. Lysak M, Berr A, Pecinka A, Schmidt R, McBreen K, Schubert I: Mechanisms of chromosome number reduction in Arabidopsis thaliana and related Brassicaceae species. Proc Natl Acad Sci USA 2006, 103(13):5224-5229.

36. Altinkut A, Raskina O, Nevo E, Belyayev A: En/Spm-like transposons in Poaceae species: transposase sequence variability and chromosomal distribution. Cellular \& Molecular Biology Letters 2006, 11(2):214-230.

37. Schubert I, Wobus U: In situ hybridization confirms jumping nucleolus organizing regions in Allium. Chromosoma 1985, 92:143-148.

38. Raskina O, Belyayev A, Nevo E: Activity of the En/Spm-like transposons in meiosis as a base for chromosome repatterning in a small, isolated, peripheral population of Aegilops speltoides Tausch. Chromosome Research 2004, 12(2):153.

39. Baeza C, Schrader O, Budahn H: Characterization of geographically isolated accessions in five Alstroemeria L. species (Chile) using FISH of tandemly repeated DNA sequences and RAPD analysis. Plant Syst Evol 2007, 269(1-2):1-14.

40. Mizuochi H, Marasek A, Okazaki K: Molecular cloning of Tulipa fosteriana rDNA and subsequent FISH analysis yields cytogenetic organization of $5 \mathrm{~S}$ rDNA and 45S rDNA in T. gesneriana and T. fosteriana. Euphytica 2007, 155(1-2):235-248.

41. Kalendar R, Tanskanen J, Chang W, Antonius K, Sela H, Peleg O, Schulman AH: Cassandra retrotransposons carry independently transcribed 5S RNA. Proc Natl Acad Sci USA 2008, 105(15):5833-5838.

42. Kapitonov $V$, Jurka J: A novel class of SINE elements derived from $5 \mathrm{~S}$ rRNA. Mol Biol Evol 2003, 20(5):694-702.

43. Mantovani M, Abel LD, Moreira-Filho O: Conserved $5 \mathrm{~S}$ and variable $45 \mathrm{~S}$ rDNA chromosomal localisation revealed by FISH in Astyanax scabripinnis (Pisces, Characidae). Genetica 2005, 123(3):211-216.

44. Wendel J, Schnabel A, Seelanan T: Bidirectional interlocus concerted evolution following allopolyploid speciation in cotton (Gossypium). Proc Natl Acad Sci USA 1995, 92(1):280-284.

45. Zhang D, Sang T: Physical mapping of ribosomal RNA genes in peonies (Paeonia, Paeoniaceae) by fluorescent in situ hybridization: implications for phylogeny and concerted evolution. Am J Bot 1999, 86(5):735-740.

46. Fukushima K, Imamura K, Nagano K, Hoshi Y: Contrasting patterns of the $5 \mathrm{~S}$ and 45S rDNA evolutions in the Byblis liniflora complex (Byblidaceae). J Plant Res 2011, 124(2):231-244.

47. Eickbush T, Eickbush DG: Finely orchestrated movements: evolution of the ribosomal RNA genes. Genetics 2007, 175(2):477-485.

48. Talbert P, Henikoff S: Centromeres convert but don't cross. PLoS Biol 2010, 8(3):e1000326.

49. Ma J, Wing RA, Bennetzen $J$, Jackson SA: Plant centromere organization: a dynamic structure with conserved functions. Trends Genet 2007, 23(3):134-139.

50. Shi J, Wolf SE, Burke JM, Presting GG, Ross-lbarra J, Dawe RK: Widespread gene conversion in centromere cores. PLOS Biol 2010, 8(3):e1000327.

51. Schindelhauer D, Schwarz T: Evidence for a fast, intrachromosomal conversion mechanism from mapping of nucleotide variants within a homogeneous alpha-satellite DNA array. Genome Res 2002, 12(12):1815-1826.

52. Roizès G: Human centromeric alphoid domains are periodically homogenized so that they vary substantially between homologues: mechanism and implications for centromere functioning. Nucleic Acids Res 2006, 34(6):1912-1924.

53. Escobar J, Glémin S, Galtier N: GC-biased gene conversion impacts ribosomal DNA evolution in vertebrates, angiosperms and other eukaryotes. Mol Biol Evol 2011.

54. Unfried I, Gruendler P: Nucleotide sequence of the 5.8S and 25S rRNA genes and of the internal transcribed spacers from Arabidopsis thaliana. Nucleic Acids Res 1990, 18(13):4011.

55. Gerlach W, Dyer TA: Sequence organization of the repeating units in the nucleus of wheat which contain 5S rRNA genes. Nucleic Acids Res 1980, 8(21):4851-4865

56. Cox A, Bennett MD, Dyer TA: Use of the polymerase chain reaction to detect spacer size heterogeneity in plant 5S-rRNA gene clusters and to locate such clusters in wheat (Triticum aestivum L). Theor App/ Genet 1992, 83(6-7):684-690.

57. MAFFT web server at the European Bioinformatics Institute. [http://www. ebi.ac.uk/Tools/msa/mafft/].
58. Librado P, Rozas J: DnaSP v5: a software for comprehensive analysis of DNA polymorphism data. Bioinformatics 2009, 25(11):1451-1452.

59. RaxML BlackBox web server. [http://phylobench.vital-it.ch/raxml-bb/index php].

60. Stamatakis A, Hoover $P$, Rougemont J: A rapid bootstrap algorithm for the RAxML web servers. Syst Biol 2008, 57(5):758-771.

\section{doi:10.1186/1471-2229-11-126}

Cite this article as: Lan and Albert: Dynamic distribution patterns of ribosomal DNA and chromosomal evolution in Paphiopedilum, a lady's slipper orchid. BMC Plant Biology 2011 11:126.

\section{Submit your next manuscript to BioMed Central and take full advantage of:}

- Convenient online submission

- Thorough peer review

- No space constraints or color figure charges

- Immediate publication on acceptance

- Inclusion in PubMed, CAS, Scopus and Google Scholar

- Research which is freely available for redistribution

Submit your manuscript at www.biomedcentral.com/submit
Biomed Central 